\title{
Relationship between diarrhea and Clostridium difficile
}

\author{
Ruxandra Laza1", Alexandru Crişan', Emilia Nicoară', Narcisa Nicolescu1', Sorina Laitin', Oana Plavițu², Karina Bota² \\ From The 9th Edition of the Scientific Days of the National Institute for Infectious Diseases Prof Dr Matei Bals \\ Bucharest, Romania. 23-25 October 2013
}

\section{Background}

With the widespread use of antibiotics, Clostridium difficile bacillus, normal resident of the colon, became more frequently involved in the production of pseudomembranous colitis.

The fact that in the Clinic of Infection Diseases II Timişoara we have registered many cases in the last 8 month, led to the following questions: a) has the disease occurred in the context of a particular field or therapeutic act (interventions on the digestive tract); b) were there flaws in the oversight of the hygiene state; $\mathrm{c}$ ) are we witnessing a process of infection "pathomorphosis"; d) is the only evidence of additional diagnostic efficiency measure.

\section{Methods}

Clostridium difficile was found to be involved in triggering diarrheal syndrome in 32 patients hospitalized in the period January-August 2013; the authors aim to analyze the possible presence of favorable conditions in which bacteria may increase aggression. The following elements have been analyzed: age, sex, comorbidities, presence and duration of antibiotic therapy prior to the onset of diarrheal disease, the origin of the case (from the hospital or family), data on disease evolution.

\section{Results}

Clostridium etiology represented $44 \%$ of all cases of hospitalized diarrhea in the mentioned range (94 cases). $62 \%$ of the patients analyzed were aged over 60 . In patients with diarrhea caused by $C$ difficile multiple comorbidities have been reported in $87.5 \%$, malignancies in $18.75 \%$. Antibiotic therapy was present in $87.5 \%$ of cases. $65 \%$ of patients had undergone surgery (digestive, uro-genital, cardiovascular, osteoarticular). The evolution was favorable in $62 \%$ of

\footnotetext{
* Correspondence: ruxi_martincu@yahoo.com

${ }^{1}$ Victor Babeş University of Medicine and Pharmacy, Timişoara, Romania

Full list of author information is available at the end of the article
}

patients, $25 \%$ had recurrence, death was reported in $12 \%$ of cases. The disease was linked with hospital contact in $97 \%$ of cases.

\section{Conclusion}

A high percentage of cases with diarrhea caused by $C$ difficile were noticed in immunocompromised patients. In patients without significant pathological past, the first interpretation seems to be nosocomial character. The diseases that have been reported in patients without pathological past, draw attention on the pathomorphosis process, amending the etiology, epidemiology and clinical infectious diseases profile.

\section{Authors' details}

${ }^{1}$ Victor Babeş University of Medicine and Pharmacy, Timişoara, Romania. ${ }^{2}$ Dr. Victor Babeş Clinical Hospital of Infectious Diseases and Pneumology, Timişoara, Romania.

Published: 16 December 2013

doi:10.1186/1471-2334-13-S1-P48

Cite this article as: Laza et al:: Relationship between diarrhea and Clostridium difficile. BMC Infectious Diseases 2013 13(Suppl 1):P48.

\section{Submit your next manuscript to BioMed Central and take full advantage of: \\ - Convenient online submission \\ - Thorough peer review \\ - No space constraints or color figure charges \\ - Immediate publication on acceptance \\ - Inclusion in PubMed, CAS, Scopus and Google Scholar \\ - Research which is freely available for redistribution

